\title{
WORK ETHICS OF SPECIAL EDUCATION TEACHERS IN SOUTH KOREA ${ }^{1}$
}

\author{
HwaChoon Park \\ Korea Research Institute for Vocational Education and Training (South Korea)
}

\begin{abstract}
The purpose of this study was to examine the work ethic attributes of special education teachers in South Korea, specifically for gender and experience. A total of 182 special education teachers participated in the Korean version of the Occupational Work Ethic Inventory-Short Form (KOWEI-SF) and provided usable data. An independent t-test was performed to compare means of male and female teachers. Next, a series of one-way analysis of variance (ANOVA) was performed with post hoc tests to compare teachers' work ethic for the experience. The results revealed that male teachers scored higher than female teachers in work ethic with $t(180)=3.634, p<.001$ (two-tailed), $r=.26$ and that special education teachers with $0 \sim 5$ years of experience scored the highest $(M=6.02, S D=0.55)$, those with 11 15 years the second $(M=5.77, S D=0.63$, and those with $6 \sim 10$ years of experience were the lowest $(M=5.67, S E=0.59)$. The difference (.354) between the two groups: $0 \sim 5$ years and $6 \sim 10$ years was statistically significant with $F(2,166)=5.655, p<.01$, partial $\eta^{2}=.064$. The results of the study can be used as materials for developing professional development programs for special education teachers in Korea.
\end{abstract}

Keywords: Teachers' work ethic, special education teachers, teaching experience and work ethic.

\section{Introduction}

To sustain society and create new things, human beings should work. Work has various meanings. Work can be an expression of one's life, talents, and gifts. People can bring benefits to the community they belong to via work. Individuals can grow mentally and spiritually by working. Thus, work is intrinsically good. To do good work, a strong work ethic is needed. Work ethic is defined as "a cultural norm that advocates being personally accountable and responsible for the work that one does and is based on a belief that work has intrinsic value" (Hill \& Petty, 1995, p. 60). Past studies on work ethic focused on common workers and examined for educational levels (Harvell, 2009; Kim, 2007; Park \& Moon, 2018), positions (supervisors vs. jobseekers; Hill \& Fouts, 2005), generations (Baby Boomers, X-ers, and Millennials; Harvell, 2009; Park \& Hill, 2018b), types of employment (tenured, non-tenured, and self-employed; Park \& Moon, 2018), and genders (Harvell, 2009; Kim, 2007; Park \& Hill, 2018b).

Many instruments to measure individuals' work ethic have been developed as well. Most of them developed in western countries such as America were based on Weber's Protestant ethic and have been modified. Examples include the Protestant Ethic (Goldstein \& Eichhorn, 1961), the Pro-Protestant Ethic Scale (Blood, 1969), the Protestant Work Ethic Scale (Mirels \& Garrett, 1971), the Eclectic Protestant Ethic Scale (Ray, 1982), Work Ethic Scale (Blau \& Ryan, 1997), the Multidimensional Work Ethic Profile (Miller, Woehr, \& Hudspeth, 2002), and New Multidimensional Work Ethic Scale (Mann, Taber, \& Haywood, 2013). Measures of work ethic which were not based on a certain religion but based on theories of work and employability skills have been developed as well. Examples are the Occupational Work Ethic Inventory (Petty \& Hill, 1995), Georgia Department of Technical and Adult Education (GDTAE) Work Ethic Scale (Boatwright \& Slate, 2002), the Employability Skills Assessment (Park \& Hill, 2016), and the Occupational Work Ethic Inventory-Short Form (Park \& Hill, 2018a).

In the past, Korean people regarded teaching as a calling (or a vocation), which means more than simply working. However, in contemporary society, teaching is considered a professional career. Even though various principles and codes of conduct for teachers have been developed, work ethic attributes for teachers have rarely been studied in Korea. Specifically, studies on the work ethic of special education teachers are sparse. Therefore, this study aimed to examine work ethic of special education teachers in South Korea.

${ }^{1}$ Note. This work was supported by a National Research Foundation of Korea grant funded by the Korean Government (2018S1A5A8029526). HwaChoon Park: hcpark@krivet.re.kr 


\section{Methods}

\subsection{Sample}

A total of 182 K-12 special education teachers in South Korea participated in the online survey in February 2020. Female teachers were 138 (75.8\%; see Table 1).

Table 1. Demographic and Study Variables $(n=182)$.

\begin{tabular}{llll}
\hline Variable & Category & $\mathrm{n}$ & $\%$ \\
\hline Gender & Female & 138 & 75.8 \\
Male & 44 & 24.2 \\
& Kindergarten & 10 & 5.5 \\
& Elementary & 40 & 22.0 \\
Middle & 20 & 11.0 \\
Experience & High School & 29 & 15.9 \\
& Special & 83 & 45.6 \\
& $0-5$ years & 60 & 33.0 \\
& 6-10 years & 59 & 32.4 \\
Education & $11-15$ years & 50 & 27.5 \\
& $16-20$ years & 12 & 6.6 \\
& 21 years or more & 1 & .5 \\
BA degree & 132 & 72.5 \\
& MA degree & 48 & 26.4 \\
& Doctorate & 2 & 1.1 \\
& Metro city & 60 & 33.0 \\
& Middle size city & 100 & 54.9 \\
& Local & 22 & 12.1 \\
\hline
\end{tabular}

\subsection{Measures}

Teachers Occupational Work Ethic. To measure special education teachers' work ethic, the Korean version of the Occupational Work Ethic Inventory-Short Form was used. The scale was developed by Park and Hill (2018a) to measure work ethic attributes in the workplace based on the factors of the Occupational Work Ethic Inventory (Petty \& Hill, 1994). The OWEI-SF consists of three factors the same construct as the OWEI: Interpersonal Skills, Initiative, and Dependability (Park \& Hill, 2018a). The OWEI-SF consists of 12 one- or two- word descriptors: friendly, cheerful, likable, courteous, perceptive, effective, ambitious, resourceful, following directions, following regulations, and dependable. The KOWEI-SF is a self-report scale and all the items are rated on a 7-point Likert scale (1=Strongly Disagree to $7=$ Strongly Agree). The KOWEI-SF was modified in statements instead of descriptors referring to the statements of the Employability Skills Assessment (ESA; Park \& Hill, 2016; Park \& Hill, 2018a). The modified KOWEI-SF was first used to measure Korean workers (Han, Park, Jang, Park, \& Park, 2018). In the study, the OWEI-SF was examined to consist of one factor (Han et al., 2018). In this study, the modified KOWEI-SG was used as one dimension as well. With the current sample, the internal consistency (Cronbach's alpha) of the KOWEI-SF was .85 ( $\mathrm{n}=182)$.

\subsection{Data analysis}

Descriptive statistics such as means, standard deviations, skewness, and kurtosis for each item of the KOWEI-SF were calculated. Next, the score of the KOWEI-SF was set as a dependent variable and gender and experience were as independent variables. To compare the means of the KOWEI-SF for gender: female and male, the independent $t$-test was performed. To compare means of the KOWEI-SF for experience, the $F$-test was performed to see if there were potentially differences in work ethic attributes between groups categorized based on their years of experience: $0 \sim 5$ years; $6 \sim 10$ years; and 11 15 years. The two groups of 16 20 years and 21 years or more were excluded since the sample size of each group was too small for statistical analyses. Next, a post hoc test was performed to compare means of between groups.

\section{Findings}

Descriptive statistics. The mean of the 12 items was $5.81(S D=.94)$. The mean of the item, I follow the rules even if I disagree with them, scored the highest $(M=6.43, S D=.67)$, and the item, I am eager to be successful, scored the lowest $(M=4.90, S D=1.55)$ (see Table 2). 
Table 2. Descriptive Statistics $(n=182)$.

\begin{tabular}{lcrrr}
\hline Item & $M$ & $S D$ & Skewness & Kurtosis \\
\hline The way I work is dependable. & 5.88 & .76 & -.72 & 1.48 \\
I am eager to be successful. & 4.90 & 1.55 & -.70 & -.22 \\
I am good at following directions. & 6.25 & .73 & -.68 & .07 \\
I accomplish my goals. & 5.81 & .91 & -.83 & 1.45 \\
I have good manners. & 6.21 & .74 & -.52 & -.48 \\
I do more than is required or expected of me. & 5.73 & .97 & -1.00 & 2.28 \\
I am aware of what is going on around me. & 5.73 & .99 & -.49 & -.34 \\
People like me. & 5.80 & .90 & -.32 & -.67 \\
I am a happy person in the workplace. & 5.28 & 1.23 & -.82 & .81 \\
I follow the rules even if I disagree with them. & 6.43 & .67 & -1.22 & 2.76 \\
I am friendly to other people. & 6.34 & .72 & -.69 & -.42 \\
I am resourceful to find solutions to problems. & 5.38 & 1.14 & -.84 & .96 \\
Total & 5.81 & .94 & -0.73 & 0.63 \\
Cronbach' $\alpha$ & .85 & & & \\
\hline
\end{tabular}

Work ethic attributes of special education teachers for gender. There was a statistically significant difference in the mean scores of the 12 KOWEI-SF between genders with $t(180)=3.634$, $p<.001$ (two-tailed), $r=.26$, which represents a medium-sized effect. Male teachers $(M=6.09$, $S D=0.47)$ scored higher than female teachers $(M=5.72, S D=0.61)$ (see Table 3 ).

Table 3. Work Ethic of Special Education Teachers for Gender $(n=182)$.

\begin{tabular}{|c|c|c|c|c|c|c|c|c|c|}
\hline \multirow{2}{*}{ Gender } & \multirow{2}{*}{$\mathrm{n}$} & \multirow{2}{*}{$M$} & \multirow{2}{*}{$S D$} & \multirow{2}{*}{$t$} & \multirow{2}{*}{$d f$} & \multirow{2}{*}{$\begin{array}{c}\text { Mean } \\
\text { Difference }\end{array}$} & \multicolumn{2}{|c|}{$95 \% \mathrm{CI}$} & \multirow[b]{2}{*}{$r$} \\
\hline & & & & & & & LL & UL & \\
\hline $\begin{array}{l}\text { Male } \\
\text { Female }\end{array}$ & $\begin{array}{c}44 \\
138\end{array}$ & $\begin{array}{l}6.09 \\
5.72\end{array}$ & $\begin{array}{l}0.47 \\
0.61\end{array}$ & $3.634^{* *}$ & 180 & .36 & .167 & .563 & 26 \\
\hline
\end{tabular}

Note. ${ }^{* *} p<.001 . \mathrm{CI}=$ confidence interval; $\mathrm{LL}=$ lower limit; $\mathrm{UL}=$ upper limit.

Work ethic attributes of special education teachers for teaching experience. Since the sample size of the two groups. The results shows that the group of $0 \sim 5$ years scored the highest $(M=6.02$, $S D=0.55), 11 \sim 16$ years the second-highest $(M=5.77, S D=0.63)$, and the $6 \sim 10$ years the lowest highest $(M=5.67, S E=0.59)$ (see Table 4).

Table 4. Descriptive Statistics of Special Education Teachers' Work Ethic for Experience $(n=169)$.

\begin{tabular}{|c|c|c|c|c|c|c|}
\hline \multirow{2}{*}{ DV } & \multirow{2}{*}{ Group } & \multirow{2}{*}{$n$} & \multirow{2}{*}{$M$} & \multirow{2}{*}{$S D$} & \multicolumn{2}{|c|}{$95 \% \mathrm{CI}$} \\
\hline & & & & & LL & UL \\
\hline \multirow{4}{*}{ Work ethic } & Total & 169 & 5.82 & 0.61 & 5.67 & 5.98 \\
\hline & $0 \sim 5$ years & 60 & 6.02 & 0.55 & 5.87 & 6.17 \\
\hline & $6 \sim 10$ years & 59 & 5.67 & 0.59 & 5.52 & 5.82 \\
\hline & $11 \sim 15$ years & 50 & 5.77 & 0.63 & 5.61 & 5.94 \\
\hline
\end{tabular}

The result of the $F$-test revealed that there was a significant difference in the mean scores in between at least one pair of groups with $F(2,166)=5.655, p<.01$, partial $\eta^{2}=.064$, which represents a small-sized effect (see Table 5).

Table 5. The Results of Between-Subjects Effects $(n=169)$.

\begin{tabular}{|c|c|c|c|c|c|c|}
\hline & Type III SS & $d f$ & MS & $F$ & Sig. & Partial $\eta^{2}$ \\
\hline Corrected model & $3.929^{\mathrm{a}}$ & 2 & 1.964 & 5.655 & .004 & .064 \\
\hline Intercept & 5687.134 & 1 & 5687.134 & 16370.392 & .000 & .990 \\
\hline Experience & 3.929 & 2 & 1.964 & 5.655 & .004 & .064 \\
\hline Error & 57.669 & 166 & .347 & & & \\
\hline Total & 5794.806 & 169 & & & & \\
\hline Corrected total & 61.598 & 168 & & & & \\
\hline
\end{tabular}


The result of the pairwise comparisons between groups revealed that there was a significant difference in the mean scores between $0 \sim 5$ years and $6 \sim 10$ years and $0 \sim 5$ years group scored .354 $(p<.05)$ higher than the $6 \sim 10$ years group (see Table 6$)$. However, there were no statistically significant differences between $0 \sim 5$ years and 11 15 years and between $6 \sim 10$ years and 11 15 years (see Table 6).

Table 6. Work Ethic of Special Education Teachers for Teaching Experience $(n=169)$.

\begin{tabular}{|c|c|c|c|c|c|c|c|}
\hline \multirow{2}{*}{ DV } & \multirow{2}{*}{ Group I } & \multirow{2}{*}{ Group J } & \multirow{2}{*}{$I-J$} & \multirow{2}{*}{$S E$} & \multirow{2}{*}{ Sig. } & \multicolumn{2}{|c|}{$95 \% \mathrm{CI}$} \\
\hline & & & & & & $\mathrm{LL}$ & $\mathrm{UL}$ \\
\hline Work & $0 \sim 5$ years & $6 \sim 10$ years & $.354^{*}$ & .108 & .004 & .099 & .610 \\
\hline ethic & & $11 \sim 15$ years & .251 & .113 & .071 & -.016 & .518 \\
\hline & $6-10$ years & $0-5$ years & $-.354^{*}$ & .108 & .004 & -.610 & -.099 \\
\hline & & $11-15$ years & -.104 & .113 & .632 & -.372 & .164 \\
\hline
\end{tabular}

Note. ${ }^{*} p<.05 . \mathrm{CI}=$ confidence interval; $\mathrm{LL}=$ lower limit; $\mathrm{UL}=$ upper limit.

\section{Conclusions and discussion}

The result of the study that there was a difference in work ethic attributes for gender is consistent with several previous studies (e.g., Kim, 2007; Park \& Hill, 2018b; Park \& Moon, 2018), which revealed that men workers scored higher in some of work ethic attributes, initiative, and thoughtfulness than women workers did. Previous studies also showed that there was a difference in work ethic for experience (e.g., Kim, 2007) that the more experienced, the stronger work ethic. However, special education teachers in South Korea showed that 0 5 years group scored the highest, which may imply that their attitudes toward students with disabilities may be more professional than the other groups due to the different curricula in colleges they had taken as pre-service teachers. The results of the current study could be used as materials for developing professional development programs for special education teachers in Korea. Further studies may include why teaching experience can affect special education teachers' work ethic via interviews of teachers.

\section{References}

Blau, G. \& Ryan, J. (1997). On measuring work ethic: A neglected work commitment facet. Journal of Vocational Behavior, 51, 435-448.

Blood, M. (1969). Work values and job satisfaction. Journal of Applied Psychology, 53(6), 456-459. doi: $10.1037 / \mathrm{h} 0028653$

Boatwright, J. R., \& Slate, J. R. (2002). Development of an instrument to assess work ethics. Journal of Industrial Teacher Education, 39(4).

Goldstein, B., \& Eichhorn, R. L. (1961). The changing Protestant Ethic: Rural patterns in health, work, and leisure. American Sociological Review, 26(4), 557-565.

Hill, R. B., \& Petty, G. C. (1995). A new look at selected employability skills: A factor analysis of the occupational work ethic. Journal of Vocational Education Research, 20(4), 59-73.

Kim, S. J. (2007). Identifying work ethic constructs using a Korean translation of the OWEI. (Doctoral dissertation). Retrieved from http://dbs.galib.uga.edu/cgi-bin

Mann, M. J., Taber, T. D., \& Haywood, K. J. (2013). Work ethic revisited: Identifying and operationalizing new dimensions of work ethic a century after Weber. Journal of Business Disciplines, 11(1), 65-101.

Miller, M. J., Woehr, D. J., \& Hudspeth, N. (2002). The meaning and measurement of work ethic: Construction and initial validation of a multidimensional inventory. Journal of Vocational Behavior, 59, 1-39. doi:10.1006/jvbe.2001.1838

Mirels, H., \& Garret, J. (1971). Protestant ethic as a personality variable. Journal of Consulting and Clinical Psychology, 69, 40-44. doi:10.1037/h0030477

Park, H. \& Hill, R. B. (2016). The employability skills assessment: Measuring work ethic for research and learning. Career and Technical Education Research, 41(3), 175-192.

Park, H. \& Hill, R. B. (2018a). Development and validation of a short form of the occupational work ethic inventory. Journal of Career and Technical Education, 32(1), 9-28.doi:10.21061/jcte.v32i1.1588.

Park, H., \& Hill, R. B. (2018b). Psychometric properties of the Korean employability skills assessment and Korean work ethic. Career and Technical Education Research, 43(1), 19-40. doi:10.5328/cter43.1.19. 
Park, H., \& Moon, S. T. (2018). 한국인의 직업윤리의 현황: 학력, 직업유형, 고용형태별 비교 분석 [Work ethics of South Koreans for level of education, occupation, and employment status]. 진로교육연구 [The Journal of Career Education Research], 31(1), 175-202. Link: http://www.dbpia.co.kr/Journal/ArticleDetail/NODE07408579.

Petty, G. C., \& Hill, R. B. (1994). Are women and men different? A study of the occupational work ethic. Journal of Vocational Education Research, 19(1), 71-89.

Ray, J. J. (1982). The Protestant ethic in Australia. Journal of Social Psychology, 116, 127-138. doi:10.1080/00224545.1982.9924402 